\title{
The "Outsourcing” As An Instrument of Competitiveness in the Business Consulting Industry
}

\author{
Renato Lopes da Costa \\ Doctoral Student in General Management, Strategy and Organizational Development \\ in the Superior Institute of Labour Studies and Business \\ University Institute of Lisbon, Portugal
}

Tel: 35-19-6463-5585Ｅ-mail: renatojlc@hotmail.com

\author{
Nélson Santos António \\ Doctor in Management by Bergischen Universitat
}

Wuppertal (Germany), and Professor in the Superior Institute of Labour Studies and Business

University Institute of Lisbon, Portugal

E-mail: njsantonio@gmail.com

\begin{abstract}
In an era of particularly intense competition, the consulting services are becoming an increasingly important source of aid for strategic making and an important way to increase efficiency and quality in the various business activities. Many managers consider the consulting services as an influential and powerful tool for organizational change, bringing new life to the organization. The purpose of this article is to study this situation. We will carry out a study in one of the biggest Portuguese private bank, in order to show the real value of management consultancy when it combines, a broad view of business to study a set of skills closely linked to the relationship between service and market and, when it is focusing on "core" competencies, resources and offers increasingly facilitating the well being of the client, ie. showing how a company can foster creativity and dynamism in the activities of companies when operates through the potentials of TIG (information technology management).
\end{abstract}

Keywords: Outsourcing, Development, Operational Efficiency, Organizational Change, Coordination and Control. 


\section{Instruction (Introduction)}

The increasing pressure from markets, characterized by intense competition and instability, lead organizations and people to rethink their strategies in dealing with the other parts. In this context, the organizations will be guided to their core areas (core business), freeing themselves from areas/activities which do not master, the dependence on external/outside supply sources increases (Lopes da Costa, 2009).

The complexity and turbulence here described (Canback, 1998) corroborates with no doubt Bruce Henderson's thought (1979), the founder of BCG (Boston Consulting Group). Bruce Henderson assumed that the business world is a world of natural selection, where only the strongers survive and the focus should be primarily directed towards a good understanding of the environment.

The organizations should be trough in an economic, political, organizational and individual perspectives, where the market and the clients are fundamentally the two dominant focus in terms of social relations (Du Gay, 2005). Other issues such as portfolio, employment contract, internal markets, outsourcing and organizational change, are other important research topics around the world. (Barley and Kunda, 2004; Beer and Nohria, 2000).

According to Canback (1998), these and other management fields are what constitutes the development of strategic disciplines in organizations and have been widely disseminated by the management consulting sector. Canback describes also the consulting industry as the path of success that must be embraced by companies in the context of its strategic direction and its professionals as true disseminators of the complex phenomenon of enterprise evolution up to now.

Although the management consulting industry date back from the time of Frederick Taylor, Henry Gantt, Arthur D. Little, Harrington Emerson and Edwin Booz, i.e. from the beginning of the $20^{\text {th }}$ century, all of them with invaluable contributions to management science in general and operational efficiency in particular (Canback, 1998). But it was only after the 1950s that the consulting industry started to be more visible and influential (Stryker, 1954; Drucker, 1979; Greiner and Metzger, 1983; Canback, 1999).

Since that time 1950, many companies have been recognized and have contributed to the historical conceptualization of the sector, albeit from the 1960's began to be recognized the real developments in this area. The first strategy and strategic consulting concepts were developed and implemented in 1963 by Boston Consulting Group. As we said before, BCG was founded by Bruce Henderson a former Arthur D. Little partner. From this date a second generation of experts started to contribute to what would be today the consultant industry as Bain and Company, Strategic Planning Associates, Braxton Associates, Lek Partnership and Monitor Company (Canback, 1998).

This remarkable transformation is illustrative of what has become the industry. Since its inception, i.e, a significant element in the current-dominant services sector and in the actual knowledge of the economy, and for this reason that the consultancy has appeared linked to 
new forms of "smart" management knowledge in its various forms (Fincham and Clark, 2002), being assigned to the consultants the key role in terms of creation, dissemination and transfer of new management ideas, and, not only purely commercial ideas, but also all those which are directly linked to the truth management practices to be adopt.

But, analyzing this context in a retrospective way and paraphrasing Porter (1980), between 1950 and mid-1980, the main topic (concern) analyzed by the consultant industry was (for the consultancy study was mainly focused on) organizational development. The main strategy's aim was to identify a particular problem and then to solve it.

However, many of the absolute truths concerning how to manage organizations today, are being increasingly discussed and questioned. The increasingly complex world we live in, where seemingly disparate events are interrelated and technological developments are blurring the boundaries between the sectors of economic activity, requires a new way of thinking. (António, 2006).

These and other concerns have also focused the attention of the current literature on management consultancy. According to Fincham and Clark (2002), these paradoxes are the reasons why actual academic researchers bring this issue to the study of management consulting. According to the authors, the consulting sector enables the management outsourcing and the leverage effects of innovation given by the parallelism between the consultancy affairs, the central management structures and processes and the excellent management of several new paradoxes by practitioners like; think long-term, but to show immediate results; innovate without losing efficiency; cooperate but also compete; work in teams but being evaluated in individual terms; be flexible without breaking the patterns; live with real increasingly virtual; remain free, but is increasingly networked; seek perfection in the midst of fast; be aggressive without losing the emotion and respect for others; act quickly by impulse, but with awareness and responsibility; being an entrepreneur, but constantly changing and innovating.

But are these modern ways of seeing management disseminated by consultants (Fincham and Clark, 2002)? Are them mediators and generators and distributors of new knowledge (Thrift, 2005)? Are their ideas reflected and dominant in the knowledge management and organizational learning (Sturdy, 2009)?

The case study carried out in one of the biggest Portuguese private banks in monitoring and evaluation of three different IT projects in the area of treatment of values, conducted by consultants of a major consulting company in Portugal tells us so.

The critique normally related to the consultants is to consider them as "rational" people, whose emphasis is focused on cutting costs and jobs to cope with immediate problems (O'Shea and Madigan, 1998; Craig, 2005 ). This critique is widespread. It also evident the consultants' attention in searching a set of products and services that meet in the future, their "Shareholders" needs, normally through a careful management and coordination of resources. This new management brings a new life to the organization and to the procedural chain of the 
company. The new management proposed by the consultants advocates normally the outsourcing of some activities (the non key activities). Doing so, the enterprises can reduce fixed costs and the managers and can concentrate their efforts in what is determinant to create value.

The focus is placed on the contribution, conceptualization and understanding of the nature of consulting work (Fincham and Clark, 2002) and the real value of consultants in the way that they show the same value to their clients (Alvesson, 1993; Clark, 1995; Starbuck, 1992).

This article aims to illustrate exactly these assumptions, showing from several reports from senior bank managers that the consultants may be in fact powerful influencers of organizational change (Sturdy and Wright, 2008). They provide tailored technical knowledge base and behavioral to help their customers and improve the organizational practices of companies.

In fact, following the line of evolutionary study of organizational strategy (from the moment of positioning) based on building and defending competitive advantage versus the moment of movement characterized by the transience of the advantages and the importance of innovation (António, 2006), particularly, in an era of intense competition, the outsourcing earns in this perspective great preponderance in the new way to manage the organizations, encompassing the characteristics of the emerging networking company, from consulting firms to incorporate new types of services related to outsourcing, as reported by the interviewed senior managers as the ideal response, an option that allowed to reduce costs, improve quality and, more importantly, to provide the capacity to release resources to be focused on the business, i.e to focus on core competencies.

In this case, the strategy is the result of combining existing resources with activities and, taken together, to generate specific skills that sustain competitive advantages. The objective consists in creating value from the market's point of view, what it is contradictory with the opinion of Alvesson and Johansson (2001). According to these authors the consultants are not in possession of a set of sustainable knowledge base to support their business status and credibility. It is also against the Chinese and Western Europe vision, whose professional consulting are possessed of incredible power that in most cases comes from nothing and is reflected in something not accountable and whose visibility is nil (Micklethwait and Wooldrige, 1996; Madigan and O'Shea, 1997).

\section{Methodology}

This research was based on an exploratory case study (Yin, 1994).According to Yin, this kind of methodology is adequate to understand complex social phenomenon.

The case study research was conducted in a prestigious Portuguese private bank. We monitored and evaluated three different IT projects in the area of treatment of values, which in light of domestic programs had the objective to carry out the transformation of certain operating activities. These operating activities were considered obsolete when analyzed from a perspective of organizational development. 
This research was based on the non-participant observation conducted by a team of three consultants and two senior managers with internal interpolations where the author proved necessary in the course of action, being the work also enriched by data collected in documentary work, such as project documents and internal reports.

The data obtained had the intention of gaining new inputs about the contribution of consultants to the business strategy and generate new ideas and theories in the construction of patterns and comparisons between the business consulting and outsourcing, which results in a theoretical framework combined with empirical data based on the articulation of coherent equilibrium that should be drawn between techno-economic, political-relational and organizational systems for decision, results of a tailored and integrated management.

\section{The rise of outsourcing and the focus of careful management of resources on the field of management consulting}

While the increasing pressure of markets has led organizations and people to reconsider their strategies in dealing with the other parties, the truth is that this relationship tends to be characterized by a strong dichotomy. All the teaching given to us since an early stage says: "I win because you lose". This axiom is the source of most of the established relationships between organizations and individuals, and is characterized by being of the type win-lose (or lose-win depending on the perspective).

However, this form of relationship has proved to be inefficient in many cases because this approach degenerates into results of type lose-lose (ie, all parties lose) on a long-term. In contrast, relations win-win try to expand the value, or the available resources, by the concerned parties through integrated and cooperative negotiation processes. Therefore, the involved parties negotiate to determine the most equitable division of value.

This logic of frontier creation value leads to the business fronts tending to benefit medium and long-term options whose routines activities may be sub-contracted, adopting a logic of partnership (win-win game - Collaborative) whose border activities can come from outside in order to make the work more efficiently (distributive core whose focus is not on the operability of activities) - Figure 1.

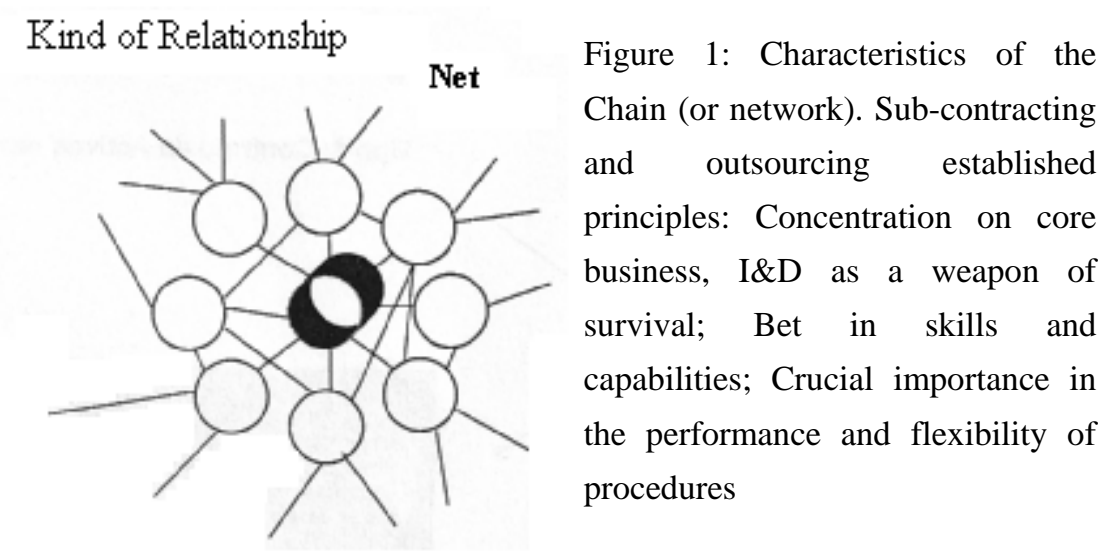

Figure 1. Characteristics of the Chain (or network). 
The relationship network shown in Figure 1 is based on the principle "Network Sourcing; Downstream Focus" conducted by a consulting firm to develop their projects. It is characterized by a low operability of the original product and process control, a delegation of tasks to third parties and economies of scale by the possibility of lowering the operating costs of existing processes (Lars and Gadd, 2008; Bergkvist, 2008). This supports the argumentation of Kipping (2002), when it states that the current rapid response of the consulting sector to the periodic changes of the interests of clients should be based on informatics based networks and expanded business systems.

At this point two questions can be made, does outsourcing have potential strategic differentiation? Which activities should be outsourced and which ones should be kept within the company? As transmitted by one of the consultants, the answer to these questions should be based on the fact that the outsourcing should be considered only in activities that involve a low strategic importance or where third parties can develop the same operations more efficiently, faster, and fundamentally with lower costs. Moreover, another consultant transcribed that focusing on essential and core skills, as well as a clear definition of the competitive position of the company is even more important.

This strategic vision and this form of business management, triggered by new economic and organizational developments, redesigns a new form of management mentioned by Arruñada and Vasquez (2006), the so called 'Contract Manufacturers'. This form of outsourcing pursues not only cost reduction but also a rapid response to market by introducing new mechanisms, techniques, procedures and technological flexibility. This allows customers to focus on innovation and the activities that are considered "core", thus enabling the combination of skills in an intelligent way, providing not only increased profitability, reduced risk and increased flexibility, but also a substantial improvement of the response capability to customer needs with the lowest cost.

Examples of this type of innovation, since the beginning of the millennium had been illustrated by Styhre and Werr (2002) when the authors mention that the consultants should include long-term links between advisers and clients or temporary outsourcing agreements in order to radically improve an operation before they start whatever with the client, because neither the critical and functionalist approach supports any kind of movement in this direction, since both appear associated to the bureaucratic ideals that block instead of supporting innovation in the relationships between client-consultant, which allows to analyze the consultancy on a basic spectrum (Ehrenberg et al, 1994) to provide incremental performance improvements.

Moreover, this approach is also question the denomination of consultants as rationalizers, often focused on cutting costs and jobs to cope with immediate problems (O'Shea and Madigan, 1998; Craig, 2005), because the main purpose of this measure is to focus the company and its workers in the "core" activities in an development perspective, outsourcing, minimizing or eliminating activities where this is not prominent or that others may actually do better and at much lower cost. In this case, intangible assets are being created, such as sharing of know-how and technological diversification, while the cost of creating this asset 
will be borne only once in the initial phase, because in the future the process will be supported by the introduction of new introduced automatisms (Porter , 1986).

Besides the advantages mentioned, as reproduced by the consultants, it is also recognized the existence of other hidden capital gains, or at least not so evident, and these derive mainly from the fact that they allow the relationship and involvement with various organizations cultures, experiences, management styles and different skills.

Among these advantages identified, the know-how that is generated and can be an important source of innovation and change, the possibility of partners to do benchmarking and make contact with some best practices, as well, identify weaknesses from disclosure of its skills, and the opportunity to be able to be changed some management processes, this because some partners often turn out to be more demanding than their own end customers.

Thus, the present developments undertaken by consultants in the projects analyzed have been responding to foundations of McLarty and Robinson (1998), when mentioning the consultants should provide important knowledge for the client and do in order to contribute as an added value, which represents in this case that we are in presence of professional drivers of change with completely objective advices in the developing of their corporate customers. What finds in fact, is that improving the management capacity, it became a matter of survival for organizations and technologies have redefined the concepts of time and space for a new context and new contexts involving change, action, and dynamism.

Organizations are to be viewed from this perspective in an economic, political, organizational and individual optic (Du Gay, 2005) and developments such as outsourcing and organizational imperative change continue to dominate organizational research around the world (Barley and Kunda, 2004; and Beer Nohria, 2000; Sturdy and Wright, 2008).

\section{Model Management dimensional Systemic Management Consulting}

In order to conceptualize all data hitherto analyzed it is necessary to build a conceptual framework that enables connect the management model of outsourcing included in the projects developed in this case study (IT projects), the integrated system approach in the perspective of design planning from the economic, political and organizational dimensions and, identifying the different roles of consultants (Ludgreen and Blom, 2009) in the development of strategic work that is generated by the different vertices of analysis of this model - Figure 2. 


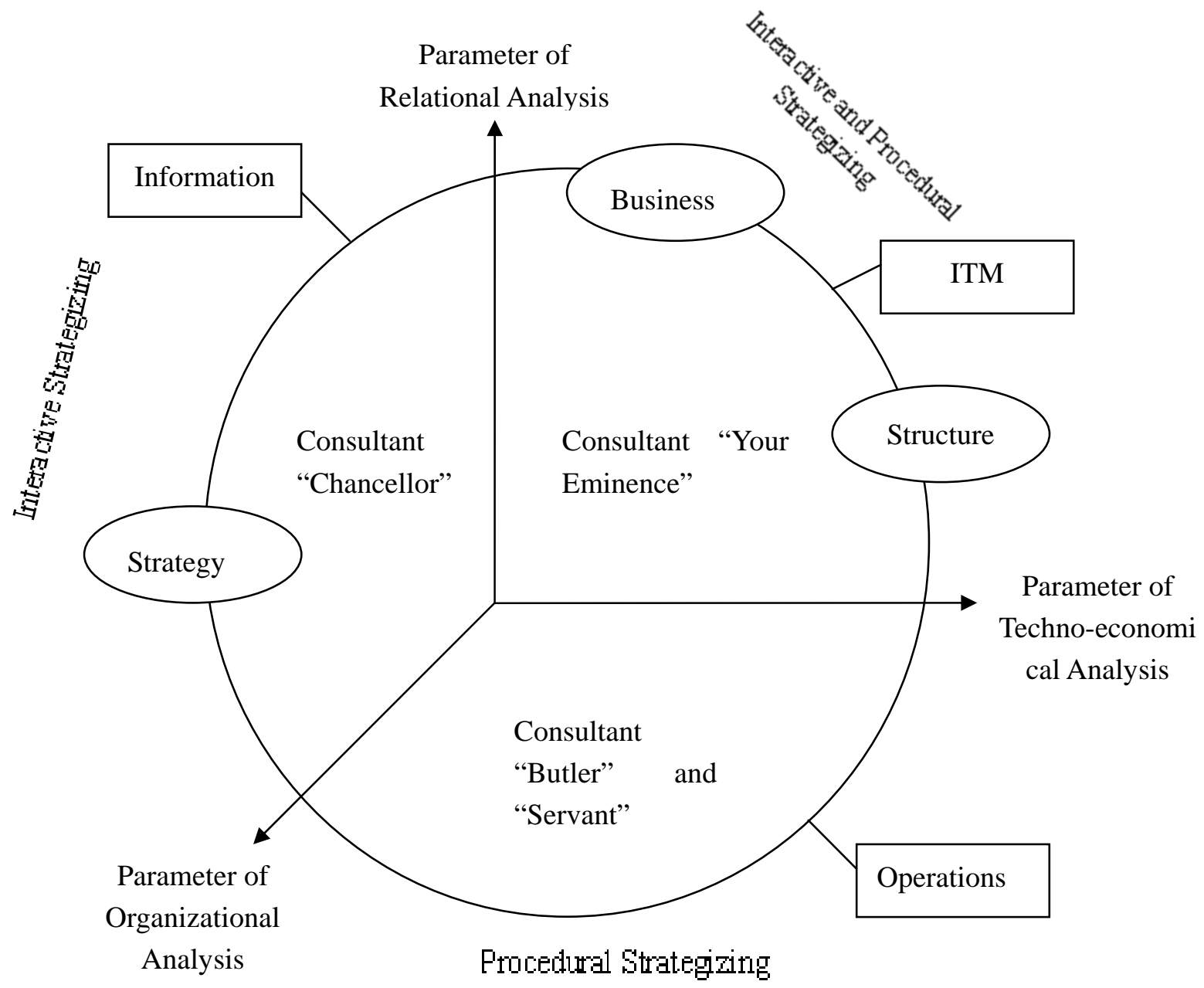

Figure 2. Tridimensional Systemic Management Model of Management Consultancy

This model consists on three axis (business, strategy and structure) and three lines that allow better positioning the problems of the organization (information, operations, information technology management (ITM).

The heart of the model is the place of business support, which is covered by the architecture shown in figure 2, being the strategic components, structural information, information technology and operational management to investigate the fields of activity in detail and definition of the best strategy to adopt. In other words, this model has an essential function of management that allows defining the diversification strategy to develop without the manager being an expert in technology management.

Moreover this approach induces an integrated component system from the perspective of planning conception through three dimensions - economic, policy and organizational. 
A strategic decision is thus defined as the articulation of coherent balance established between technical-economic, political and organizational systems decision, resulting from a tailored and integrated management.

The technical-economic system embodies the means of production of strategic planning, with systematic rigor and detail, involving the macro and micro means, or in other words, the global, sectoral and specific and yet the systemic environment of the firm. What in the case of a contractual outsourcing basis refers to an option to reduce costs, improves quality and provides the ability to free up resources so that they are focused on business, focusing the company on core competencies.

The politico-relational component shows in turn the perspective of the strategic behavior of actors/systems, in the presence of systemic environment, in this case making merge the network society, trough consulting firms to incorporate in its customer's companies new types of services related to outsourcing contract basis.

At the other end of the system it is important to also consider the organizational system, which includes the morphological, decision-making, bureaucratic, relational and control systems in confront with systemic environment, which assumes that in consulting works the tasks of the clients may well be linked only to residual activities of monitoring and control.

Thus, these systems provide a deeper insight and are complementary, and should be understood and apply globally, otherwise the analysis is necessarily limited.

Making guidelines and a conceptual lecture of the model components and framing the strategic-economic, operational (organizational) and relational components it is easy to perceive that the appropriate requirements of organizational development must be fundamentally linked to the development of new automation procedure based on information technologies management, as a resource yet in a contractual basis linked through outsourcing services in the implementation of new methods to solve a set of structural problems.

The information, here enhanced by information technologies and communication, assumes the role and importance due in creating value, in a market where knowledge of the customer, competitors, suppliers and other economic managers, it becomes vital for the design and implementing business strategies.

In this context, the business concept represented here is closely related to the binomial between service/market, incorporating in the midst a highly technological component in a transversal character, seeking to offer their customers (internal and external) a facilitator of welfare, just as which represents the saving of time and resources to companies by leveraging the ITM.

Illustrating the conceptual framework of the model and the strategic-economic, operational (organizational) and relational components is important to identify the different roles of consultants in developing these activities, including how they act, what kind of work they do, what kind of interactions that sustain this work and with what resources. 
Converging then the identification of the different roles of consultants from Lundgren and Blom (2009) in relation to activities that constitute its strategic work in terms of practices that develop - The consultant in the role of "Chancellor", "Your Eminence", "Butler "and" Servant "- the position of "Chancellor "is directly linked to the parameter of relational analysis, which incorporates the strategic component and knowledge (information about the environment), which implies that much of their time is spent in the most various types of interactions, whether of a formal and/or informal character in order to provide the construction of an information structure that allows them to easily set a strategic direction and influence managers and executives in strategic decisions to develop.

For its part, "Your Eminence" still has access to some interactive nature of interventions with managers and customers, the fact that are associated to an organizational status unofficial limits them in this type of intervention, what makes them sought more often to give advice and develop ideas and actions that create value added in terms of conception of a particular strategic business structure who wants to be carried out by the consultant "Chancellor". Therefore, the consultant's role in this quadrant is directly connected to the parameter of techno-economic analysis incorporating the components of structure, business and information technology, result of the interactive work, but sometimes also procedural who "forced" to develop.

At the opposite site of the figure we have the position of the "Servant", whose role is fundamentally more limited or null in terms of activities that involve interactivity, being in this conjuncture these consultants more related to a procedural basis on their activities, being essentially linked to knowing "do", not taking in the majority of time any possibility to influence any decisions, which in the figure is represented by the parameter of organizational analysis and "operations."

Along the line of "Servant", the role of "Butler" is mostly limited, although it can enjoy an official status as the first does not hold. The activities of the "Butler" are typically linked to the development, compilation and presentation of information about a particular context that were tasked to work, which the consulting approach is described as a "Senior Servant," which allows some organizational visibility and exposure status that the position of "Servant" does not hold at all.

\section{Conclusions and directions for future studies}

Paraphrasing Drucker (1979), the management consultancy sector should not be viewed as a science, nor as an art, but must always be something to consider in scenarios of uncertainty and unpredictability face essentially to the revolution of information technology experienced in this early twenty-first century, and although many authors do not have this view about this phenomenon, a conclusion can be drawn is that your ability to solve problems, the techniques that they apply and the role that they represent in the global economy will not certainly falter and this industry will continue to be the focus of study for many people, as a result not only of the annual growth of 20\% that has experienced since 1980 (Canback, 1999), but also by the preference for this career for most students that coming out every year from universities and business schools and that makes indubitably this sector a field of opportunities, 
foreseeing that the consultancy industry continue to raise a topic research for researchers for many long years.

So, this study had as main objective, to evidence the importance of consulting sector in face to the current needs of an organizational climate increasingly demanding, is therefore necessary to present theoretically a three-dimensional systemic model, that makes possible to link management consultancy sector to an strategic base developed with resource to the outsourcing, illustrating a very simple reality, does not exist a better way or reason to proceed to outsourcing, and even exists, is guaranteed that will change with time, with the pressures of business, politics and the technology itself. In fact, the only thing we can agree on is that outsourcing is an issue that deserves to be considered given the potential it holds.

Here the consultant's role may be crucial, providing important knowledge for the client to contribute as an asset in the amount of certain parameters that are outside the skills and experience of organizations (McLarty and Robinson, 1998), fitting perfectly in this conception the perspective of a consultant as being "hybrid" of Merton (1972) and Sturdy and Wright (2008), should act as an external actor to the organization acting as a internal agent of change, using both the functionalist and critiques visions of consultants perspective (Styhre and Werr, 2002).

Therefore concluded, that there is no doubt that outsourcing is a virtual inevitability, whose role of consultant may contribute to the formation of certain identities, practices and ideas that can promote the organizations in various ways (Sturdy \& Wright, 2008) and thus not likely that the interest of the organizations regarding the "business process outsourcing decrease in the near future, and this issue will surely continue to touch the lives of many of the top managers, professionals from information systems and the users themselves that need to adjust to new people, cultures and procedures.

In this measure, the change must always be seen as an opportunity and should already be working in such a way as to avoid the risks are inherent. The consultants should work here as real drivers of change, with totally objective advice and a rigorous notion of management in terms of the switchover plans to incorporate for an efficient management of this paradigm, which also refers to the fact of having to work as a chameleon who need to feel comfortable in many roles, working out, in advance, the exact role expected before starting the project (McLarty and Robinson, 1998).

Finally, it should be noted that this research has served a very objective purpose and incorporate findings of a very specific context of a case study that cannot be generalized (Eisenhart, 1989; Yin, 1994), being necessary further investigations to conform the exploration results, in order to strengthen and develop new conceptual frameworks about the topics discussed.

\section{References}

ALVESSON, M. 1993. Organizations as Rhetoric: Knowledge-Intensive Firms and the Struggle with Ambiguity. Journal of Management Studies 30 (6): 997-1015. 
ALVESSON, M. \& Johansson, A. (2001). Professionalism and Politics in Management Consultancy Work. Reprint Series, Department of Business Administration, Lund University.

ANTÓNIO, Nelson Santos (2006). Estratégia Organizacional: Do Posicionamento ao Movimento. Edições Sílabo, $2^{\circ}$ Edição, Lisboa.

ARRUÑADA, Benito \& Xosé H. Vasquez (2006). Subcontratar e Rendibel?: Causas e Consecuencias da Especialización Produtiva na Industria. Revista Portuguesa e Brasileira de Gestão, Out/Dez, pp. 36-39.

BARLEY, S. R. and Kunda, G. (2004). Gurus, Hired Guns and Warm Bodies. Princeton University Press, Princeton, NJ

BEER, M. and Nohria, N., eds (2000). Breaking the Code of Change. MA: Harvard Business School Press, Boston.

BERGKVIST, Linda (2008). Dimensions for Describing and Explaining the Successful Outcome of the IS Outsourcing Process - Emphasising the Relationship Perspective. Industrial Marketing and Purchasing Group, Conference in Uppsala.

CANBACK S. (1998). The Logic of Management Consulting (Part One). Journal of Management Consulting, Vol. 10, $\mathrm{n}^{\circ} 2$.

CANBACK, S. (1999). The Logic of Management Consulting (Part Two). Jounal of Management Consulting, Vol 10, $\mathrm{n}^{0} 3$.

CRAIG, D. (2005). Rip Off! The Scandalous Inside Story of the Management Consulting Money Machine. The Original Book Company, London.

DRUCKER, P. F. (1979). Why anagement consultants? Em The Evolving Science of Management, Amacom, Editado por Z. Melvin e R. G. Greenwood, New York.

DU GAY, P. (2005). In Praise of Bureaucracy. London: Sage.

EHRENBERG, A., Lloyd, B. \& Seriven, J. (1994). Knowledge based on speculative consultancy. Proceedings of international Consultancy Conference, South Bank University Press, pp. 48-53.

FINCHAM, R. \& Clark, T. (2002). Preface: Management Consultancy - Issues, Perspectives, and Agendas. International Studies of Management and Organization, Vol.32, No.4, 3-18.

GREINER, L., \& R. Metzger (1983). Consulting to Management. Prentice-Hall, Englewood Cliffs, N.J.

HENDERSON, Bruce (1979). Henderson on Corporate Strategy. Abt Books, Cambridge, Mass.

KIPPING, M. (2002). Trapped in Their Wave: The Evolution of Management Consultancies. In T. Clark and R. Fincham (eds.), Critical Consulting: New Perspectives on the Management Advice Industry, pp. 21-27. Blackwell, Oxford. 


\section{Macrothink}

Journal of Management Research

ISSN 1941-899X

2011, Vol. 3, No. 1: E6

LARS, Kajsa Hulthén \& Erik Gadde (2008). Logistics Outsourcing and the Role of Logistics Service Providers from an Industrial Network Perspective. Industrial Marketing and Purchasing Group, Conference in Uppsala.

LOPES DA COSTA, R. (2009). A Coordenação dos Recursos como factor de Competitividade no Sector da Banca. Master Thesis, Management Department, INDEG ISCTE, University of Lisbon, Lisbon.

LUNDGREN M. \& Martin Blom (2009). The practice of Strategy Consultants. $25^{\text {th }}$ Egos Colloquium, Barcelona, July 2-4.

MCLARTY, R. e Robinson T. (1998). The Practice of Consultancy and a Professional Development Strategy. Leadership \& Organization Development Journal, 19 (5), 256-263.

MERTON, R. K. (1972). Insiders and Outsiders: A Chapter in the Sociology of Knowledge. The American Journal of Sociology 78(1): 9-47.

MICKLETHWAIT, J. \& Wooldridge, A. (1996). The Witchdoctors: Making Sense of the Management Gurus. Heinemann, London.

O'SHEA, J. \& Madigan, C. (1997). Dangerous Company. Nicholas Brealy, London.

O’SHEA, J. \& Madigan, C. (1998). Dangerous Company: Management Consultants and the Businesses They Save and Ruin. Penguin Books, Nova York.

PORTER, M. (1980). Competitive Strategy' Techniques for Analysing Industries and Competitors. Free Press, Glencoe, IL.

PORTER, M. (1986). Estratégia Competitiva: Técnicas para Análise de Indústrias e da Concorrência. Editora Campus, $17^{\mathrm{a}}$ Edição, Rio de Janeiro.

STARBUCK, W.H. 1992. Learning by Knowledge-Intensive Firms. Journal of Management Studies 29 (4): 713-40.

STRYKER, P. (1954). The Ambitious Consultants. Fortune, May, pp. 82-85.

STURDY, A. J. (2009). Popular Consultancy Critiques and a Politics of Management Learning?. Management Learning, 40, 4, 457-463

STURDY, A. J. \& Wright, C. (2008). A Consulting Diaspora? Enterprising Selves as Agents of Enterprise. Organization 15 (3): 427-44.

THRIFT, N. (2005). Knowing Capitalism. London: SAGE.

WERR, A. \& Styhre, A. (2002). Management Consultants Friend or Foe?. International Studies of Management \& Organization, 32(4): 43-66.

YIN, R. K. (1994). Case Study Research Design and Methods. Sage ( $2^{\text {nd }}$ edition), Thousand Oaks. 